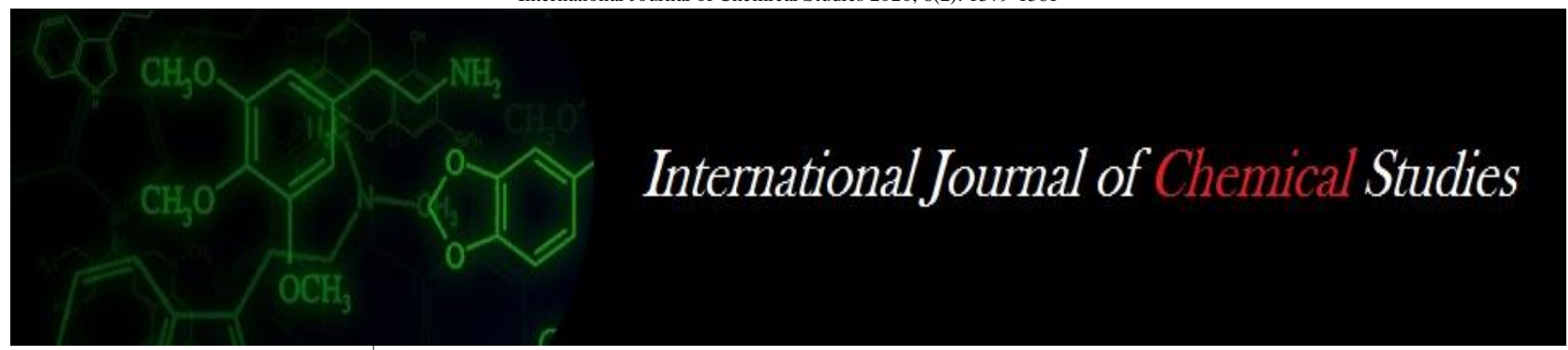

P-ISSN: 2349-8528

E-ISSN: 2321-4902

www.chemijournal.com

IJCS 2020; 8(2): 1379-1381

(C) 2020 IJCS

Received: 16-01-2020

Accepted: 20-02-2020

Pradeep Singh

Department of Horticulture,

CEDA Project, BUAT, Banda,

Uttar Pradesh, India

\section{Impact of potassium nitrate (KNO3) and gibberellic acid (GA3) on germination and growth of aonla (Emblica officinalis $\mathbf{L}$.)}

\section{Pradeep Singh}

DOI: https://doi.org/10.22271/chemi.2020.v8.i2u.8955

\begin{abstract}
The present experiment entitled impact of potassium nitrate (KNO3) and gibberellic acid (GA3) on germination of Aonla (Emblica officinalis L.) was conducted at the Green House, Department of Horticulture, Allahabad Agricultural Institute - Deemed University, Allahabad, in 2007. Seeds were sown in polybags. Polybags were filled in with well-mixed soil, sand and farmyard manure. The experiment was conducted by adopting completely randomized design (CRD) with 13 treatments each replicated three times. Treatment $T_{9}$ i.e. GA3 $400 \mathrm{ppm}$, recorded the maximum germination percentage followed by $\mathrm{T}_{10}$ i.e. GA3 $600 \mathrm{ppm}$ while the minimum was with $\mathrm{T}_{0}$ (control). Tallest seedlings were recorded with treatment $\mathrm{T}_{2}$ i.e. $\mathrm{KNO}_{3} 1.00 \%$ followed by $\mathrm{T}_{3}$ i.e. $\mathrm{KNO}_{3} 2.00 \%$ and the shortest seedlings were recorded with To (control). Maximum number of leaves per seedling was recorded with treatment $T_{9}$ i.e. GA3 400 ppm closely followed by $\mathrm{T}_{8}$ i.e. $\mathrm{GA}_{3} 200 \mathrm{ppm}$, whereas, the minimum was with to (control). Maximum number of leaflets/leaf was recorded with treatment $\mathrm{T}_{9}$ i.e. $\mathrm{GA}_{3} 400 \mathrm{ppm}$ followed by $\mathrm{T}_{8}$ i.e. $\mathrm{GA}_{3} 200$ ppm, whereas, the minimum remained with To (control).
\end{abstract}

Keywords: potassium nitrate, gibberellic acid, germination, Green House

\section{Introduction}

Aonla fruit is highly nutritive. It is one of the richest sources of vitamin-C, next to Barbados cherry (Asenjoi, 1953) ${ }^{[1]}$. It contains 500 to $1500 \mathrm{mg}$ of ascorbic acid per $100 \mathrm{~g}$ of pulp. Maximum vitamin- $\mathrm{C}$ content in aonla is found in mature fruits rather than immature. The fruit juice contains nearly 20 times as much vitamin-C as in orange juice and a single fruit is equal in anti-ascorbic value to two oranges. The fruit contains a chemical substance called Leucoanthocyanin or polyphenols, which retards the oxidation of vitamin-C (Sastry et al., 1956). The fruit is also rich in pectin and minerals like iron, calcium and phosphorus. Besides the vitamin $\mathrm{C}$ content, aonla fruits have immense nutritive value; the pulp contains Proteins $(0.05 \%)$, Fats $(0.01 \%)$, Minerals $(0.71 \%)$, Fibres $(3.4 \%)$, Carbohydrate $(14.1 \%)$, Calcium $(0.05 \%)$, Phosphorus $(0.2 \%)$, Iron $(1-2 \mathrm{mg} / \mathrm{g})$ with a high amount of pectin. Tannin if found in high quantity in barks, leaves and seeds. The aonla fruit is valued high among indigenous medicines in India. It is probably the only fruit to fill the gap of astringent food recommended by the Ayurvedic system of medicine for a balanced diet and sound health. Aonla is the main ingredient in Chavanprash. It is one of the important nutritive fruits besides its medicinal values. Dried fruit is useful in hemorrhage, diarrhoea, chronic dysentery, diabetes, cough, jaundice, etc. Aonla fruit is small, round, six lobed with hard pulp and is not commonly consumed in fresh form because of its astringent taste. Astringency in aonla fruit is due to tannin containing gallic acid, ellagic acid having glucose in their molecules, which retards the oxidation of ascorbic acid (Hanif, 1966) ${ }^{[4]}$. It is therefore, not popular as table fruit. The excellent nutritive and therapeutic values of fruit offer great potentiality for processing it into several quality products like pickles, preserves (murabba), candy, jellies, etc. Aonla is propagated by seeds as well as by budding. Aonla seeds are very poor in germination (Singh $e t$ at., 1993) ${ }^{[13]}$. This poor germination may be either due to hard seed coat or due to presence of certain inhibitors in the seed. Raising of rootstock is a major constraint in propagation of aonla. Many freshly harvested seeds also do not respond to better germination. Although aonla 
fruit is of great economic importance and assess a considerable nutritive value, till now very little is known about the distinguished physico-chemical characters in different cultivars, which can provide better knowledge to the horticulturists. There were no standard cultivars of aonla especially in Allahabad agro-climatic conditions. They were mostly known based on shape and size or after the names of places. The standardisation of a cultivar is necessary before taking up any systematic work. The crop is normally multiplied by seeds. For dry land horticultural plantation programme, seedlings have to be raised andquick and enhanced germination has to be secured. The seeds of aonla are impermeable due to hard seed coat. Impermeability and dormancy mostly associated with hard coated seeds acting as barriers in their germination and have handicapped their rapid spread even when favourable conditions subsisted (Pawshe et al., 1997) ${ }^{[5]}$. It has been reported that water soaking and heat through water is the simplest agency overcoming impermeability of seed coats and secure in increased gemmation (Venkararatnam, 1951) ${ }^{[14]}$. Aonla seeds exhibit dormancy (Rao, 1974). It has been reported that application of gibberellins breaks dormancy of seeds and results in early and enhanced seed germination (Randhawa and Negi, 1964; Bankar, 1980) ${ }^{[10,2]}$. On the other hand, the increased germination and vigorous seedlings or both have been reported in many fruit crops with soaking seeds in gibberellins (Rana and Chadha, 1965) ${ }^{[9]}$. The work on pregermination seed treatment with gibberellins, water soaking, heat through water in aonla is lacking. Plant growth regulators are often used to improve the seed germination and enhance the root and shoot growth of a number of horticultural crops. These growth regulators not only increase the percentage of germination but also accelerate the growth of the seedlings. Several workers have reported that treatment of seeds with chemicals have improved the germination as well as reduce the time taken for germination. Keeping in view the above facts, the present experiment entitled "impact of potassium nitrate (KNO3) and gibberellic acid (GA3) on seed germination and of Aonla (Emblica officinalis L.) cv. NA-4" was conducted.

\section{Materials methods}

The present experiment was conducted at the Green House, Department of Horticulture, Allahabad Agricultural Institute Deemed University, Allahabad, from February to May 2007, to study the effect of plant growth regulators on growth of root and shoot of Aonla. The Allahabad district is situated in the southern part of Uttar Pradesh at an elevation of 78 metres above mean sea level, at $25.8^{\circ} \mathrm{N}$ latitude and $81.56^{\circ} \mathrm{E}$ longitude. The climate is subtropical with boththe extremes of temperature during summer and winter. During December and January, the temperature may drop down to as low as $\mathrm{L}-2^{\circ} \mathrm{C}$ while it may exceed $48^{\circ} \mathrm{C}$ during May and June. Frost duringer and hot winds during summer are common occurrences. The age annual rainfall is about $102 \mathrm{~cm}$ with its maximum concentration during July to September with occasional showering winter. Aonla seeds of var. NA-4 were procured from the local market of Allahabad. Seeds were sown in polybags. Polybags were filled in with well-mixed soil, sand and farmyard manure. The ratio of soil, sand and FYM was 1:2:1, respectively. The seeds were sown $2 \mathrm{~cm}$ deep from the surface. One gram of gibberellic acid was weighed on a chemical balance and was transferred to a beaker with the help of soft brush to prepare half litre of stock solution of 1000 ppm. To dissolve this, $5-10 \mathrm{ml}$ of absolute alcohol was added and shaken well. Therefore, to make the stock solution of half litre of $1000 \mathrm{ppm}$, distilled water was added with the help of measuring cylinder to make the volume. Stock solution of potassium nitrate was also prepared in the same manner, as for gibberellic acid. For preparing the other required concentrations of these growth regulators, dilution method was adopted.

\section{Result and discussion}

Treatment $\mathrm{T}_{9}$ i.e. $\mathrm{GA}_{3} 400 \mathrm{ppm}$, recorded the maximum germination percentage (85.50) followed by 79.00 with treatment $\mathrm{T}_{10}$ i.e. $\mathrm{GA}_{3} 600 \mathrm{ppm}$, whereas, the minimum (35.00) was with $\mathrm{T}_{0}$ (control). Treatments $\mathrm{T}_{2}\left(\mathrm{KNO}_{3} 1.00 \%\right)$ and $\mathrm{T}_{6}\left(\mathrm{KNO}_{3} 5.00 \%\right) ; \mathrm{T}_{2}\left(\mathrm{KNO}_{3} 1.00 \%\right)$ and $\mathrm{T}_{7}\left(\mathrm{GA}_{3} 100\right.$ $\mathrm{ppm}) ; \mathrm{T}_{6}\left(\mathrm{KNO}_{3} 5.00 \%\right)$ and $\mathrm{T}_{7}\left(\mathrm{GA}_{3} 100 \mathrm{ppm}\right)$ were found statistically at par. The soaking of seed in water and gibberellic acid solution might have helped to increase the permeability of seed to GA solution and water. Further, the soaking might have helped in dilute out the inhibitors of seed germination. The growth regulators like GA have been reported to play a great role in the process of germination. With the embedded water, the embryos get activated and the process of germination is initiated. GA synthesised by enlarged embryo acts on the living cells and causes de-novo synthesis of hydrolysing enzymes particularly amylase and protease. The hydrolysed food is utilised for the growth of embryo. The endogenous GA present in the embryo might be at low concentration and therefore, exogenous application of gibberellic acid through soaking of seed might have enhanced the process of germination by way of early and higher germination. These results are in close conformity with the findings of Wagh et al. (1998) ${ }^{[15]}$ and Rahemi and Baninasab (2000) ${ }^{[7]}$.

\section{Height of seedling (cm)}

Tallest seedlings $(31.33 \mathrm{~cm})$ were recorded with treatment $\mathrm{T}_{2}$ i.e. $\mathrm{KNO} 31.00 \%$ followed by $30.20 \mathrm{~cm}$ with treatment $\mathrm{T}_{3}$ i.e. $\mathrm{KNO}_{3} 2.00 \%$ and the shortest seedlings $(13.60 \mathrm{~cm})$ were recorded with to (control). Potassium nitrate enhanced the growth at the meristematic region of the seedlings. This might be due to potassium nitrate, which has been reported to raise the ambient oxygen level by making less oxygen available for the citric acid cycle. Rajamanickam et al. (2002) ${ }^{[8]}$ and Purvey and Meghwal (2005) ${ }^{[6]}$ also reported similar results.

\section{Number of leaves per seedling}

Maximum number of leaves per seedling (35.00) was recorded with treatment $\mathrm{Tg}$ i.e. GA3 $400 \mathrm{ppm}$ closely followed by 34 .

50 with treatment Ts i.e. GA3 $200 \mathrm{ppm}$, whereas, the minimum (18.45) was with to (control). Treatments $\mathrm{T}_{3}$ and $\mathrm{T}_{5}$ (KNO3 2.00\% and 4.00\%); $\mathrm{T}_{4}(\mathrm{KNO} 3)$ and $\mathrm{T}_{5}$ (KNOs $3.00 \%$ and 4.00\%); $\mathrm{T}_{7}$ and $\mathrm{T} 10\left(\mathrm{GA}_{3} 100\right.$ and $\left.600 \mathrm{ppm}\right) ; \mathrm{T}_{7}$ and $\mathrm{T}_{8}$ $\left(\mathrm{GA}_{3} 100\right.$ and $\left.200 \mathrm{ppm}\right) ; \mathrm{T}_{8}$ and $\mathrm{T}_{9}\left(\mathrm{GA}_{3} 200\right.$ and $\left.400 \mathrm{ppm}\right)$ were found statistically at par. The beneficial effect of GA3 in increasing plant height might be attributable to the wellknown fact that gibberellins increase cell division and cell elongation when applied in proper concentration, as well as the two enzymes (amylase and protease) induced by gibberellic acid, thereby resulting in higher number of leaves per seedling. These results are in close conformity with the findings of Wagh et al. (1999) and Rahemi and Baninasab (2000) ${ }^{[7]}$. 


\section{Number of leaflets per leaf}

Maximum number of leaflets per leaf (50.00) was recorded with treatment $\mathrm{T}_{9}$ i.e. $\mathrm{GA}_{3} 400 \mathrm{ppm}$ followed by 45.00 with treatment Ts i.e. $\mathrm{GA}_{3} 200 \mathrm{ppm}$, whereas, the minimum (12.00) remained with to (control). Gibberellic acid treatment induced the amylase and protease enzymes through de-novo synthesis, which participate in the breakdown of the stored starch to simple sugars. These sugars are then translocated to the growing embryo where they provide energy for growth and development, thereby resulting in higher number of leaves per seedling. These results are in close conformity with the findings of Wagh et al. (1999) and Rahemi and Baninasab (2000) ${ }^{[7]}$.

Table: Effect of different treatments on germination percentage and growth of Aonla.

\begin{tabular}{|c|c|c|c|c|c|c|}
\hline \multicolumn{5}{|c|}{ TreatmentConcentration Germination percentage Height of seedling $(\mathrm{cm})$} & \multirow{2}{*}{ Number of leaves per seedling } & Number of leaflets per leaf \\
\hline $\mathrm{T}_{0}$ & Control & - & 25.20 & 18.45 & & 35.00 \\
\hline $\mathrm{T}_{1}$ & KNO3 & $0.50 \%$ & 2.20 & 24.80 & 14.00 & 55.00 \\
\hline $\mathrm{T}_{2}$ & KNO3 & $1.00 \%$ & 31.33 & 23.20 & 16.00 & 58.00 \\
\hline $\mathrm{T}_{3}$ & $\mathrm{KNO}_{3}$ & $2.00 \%$ & 30.20 & 22.10 & 19.00 & 47.00 \\
\hline $\mathrm{T}_{4}$ & KNO3 & $3.00 \%$ & 28.25 & 21.00 & 21.00 & 44.00 \\
\hline $\mathrm{T}_{5}$ & KNO3 & $4.00 \%$ & 27.20 & 20.50 & 25.00 & 41.00 \\
\hline $\mathrm{T}_{6}$ & KNO3 & $5.00 \%$ & 26.10 & 19.50 & 28.00 & 58.00 \\
\hline $\mathrm{T}_{7}$ & $\mathrm{GA}_{3}$ & $100 \mathrm{ppm}$ & 13.60 & 33.20 & 32.00 & 60.00 \\
\hline $\mathrm{T}_{8}$ & $\mathrm{GA}_{3}$ & $200 \mathrm{ppm}$ & 15.25 & 34.50 & 45.00 & 65.00 \\
\hline $\mathrm{T}_{9}$ & $\mathrm{GA}_{3}$ & $400 \mathrm{ppm}$ & 22.20 & 35.00 & 50.00 & 85.50 \\
\hline $\mathrm{T}_{10}$ & $\mathrm{GA}_{3}$ & $600 \mathrm{ppm}$ & 21.50 & 32.30 & 40.00 & 79.00 \\
\hline $\mathrm{T}_{11}$ & $\mathrm{GA}_{3}$ & $800 \mathrm{ppm}$ & 18.60 & 30.20 & 30.00 & 75.00 \\
\hline $\mathrm{T}_{12}$ & $\mathrm{GA}_{3}$ & $1000 \mathrm{ppm}$ & 16.80 & 29.10 & 20.00 & 69.00 \\
\hline & & $\begin{array}{c}\text { F- test } \\
\text { S. Ed. }( \pm) \\
\text { C. D. at } 5 \%\end{array}$ & $\begin{array}{c}\mathrm{S} \\
0.42 \\
0.86 \\
\end{array}$ & $\begin{array}{c}\mathrm{S} \\
0.50 \\
1.02 \\
\end{array}$ & $\begin{array}{c}\mathrm{S} \\
0.89 \\
1.84\end{array}$ & $\begin{array}{c}\mathrm{S} \\
1.11 \\
2.29 \\
\end{array}$ \\
\hline
\end{tabular}

\section{Conclusion}

From the above results, it was concluded that seed treatment with $\mathrm{GA}_{3} 400 \mathrm{ppm}$ was found suitable for germination and growth of seedlings of aonla.

\section{References}

1. Asenjoi CF. The Story of West Indian Cherry. Boletin del. Collegio-de-Quinicos de Pureto Rico. 1953; 10:8-11.

2. Bankar GJ. Effect of seed treatment with gibberellic acid on germination of seeds of winter season annuals. South Indian Hort. 1980; 28(2):60-62.

3. Fisher RA. Handbook of agricultural statistics. Achal Prakashan Mandir, 1950, 332-334.

4. Hanif M. Chemical composition of Aonla. Pakistan J. Sci. Res. 1966; 18:61-63.

5. Pawshe YH, Patil BN, Patil LP. Effect of pre-germination seed treatments on germination and vigour of seedlings in Aonla (Emblica officinalis Gaertn.). PKV Res. J. 1997; 21(2):152-154.

6. Purbey SK, Meghwal PR. Effect of pre-sowing seed treatment on seed germination and vigour of aonla seedlings. Res. on Crops. 2005; 6(3):560-561.

7. Rahemi S, Baninasab B. Effect of GA.3 on seedling growth in two wild spp. of pistachio. J. Hort. Sci. Biotech. 2000; 75(3):336-339.

8. Rajamanickam C, Anbu S, Balakrishnan K. Effect of chemicals and growth regulators on seed germination in Aonla (Emblica officinalis G.). South Indian Hort. 2002; 50(1-3):211-214.

9. Rana RS, Chadha TR. Studies on the effect of duration of after-ripening cracking of seeds and gibberellins on the cherry seed germination. Him. Hort. 1965; 6:38-40.

10. Randhawa GS, Negi SS. Preliminary studies on seedling growth in grapes (visit sp.). Indian J. Hort. 1964; 21:185186.

11. Rao SN. Annonas the legendry fruit. Indian Hort. 1974; 19(3):19-21.
12. Sastry LN, Satyanarayana MN, Srinivasan M, Subramanyan V. Physico-chemical properties of Aonla. Journal of Sci. Indus. Res. 1956; 15:70-80.

13. Singh IS, Pathak RK, Dwivedi R, Singh HK. Aonla Production and Post-harvest Technology. Department of Horticulture, N. D. University of Agriculture and Technology, Kumarganj, Faizabad, 1993.

14. Venkararatnam L. Pre-sowing treatment for seeds of some cultivated plants. Madras Agric. J. 1951; 38:103104.

15. Wagh AP, Choudhary MH, Kalwal LV, Jadhav BJ, Joshi PS. Effect of seed treatment on germination of seed and initial growth of Aonla seedlings in polybag. PKV Res. J. 1998; 22(2):176-177. 